\title{
PUBLIC AND PRIVATE SECTOR IT GOVERNANCE: IDENTIFYING
}

\section{CONTEXTUAL DIFFERENCES}

\author{
John Campbell \\ Craig McDonald \\ Tsholofelo Sethibe \\ Faculty of Information Sciences and Engineering \\ University of Canberra, Bruce ACT 2601
}

\begin{abstract}
This paper highlights systemic contextual differences and the unique IT Governance issues that might arise in public and private sector organizations. Public sector organizations constitute a significant component of economic activity in most countries. Like their private sector counterparts, many public sector agencies are struggling to cope with reduced or inadequate IT budgets and are continuously looking for ways to extract maximum value from IT resources. While both sectors face similar managerial-level IT issues and challenges, we argue that there are systemic differences between private and public sector organizations suggesting that a one size fits all approach to IT Governance may not apply.
\end{abstract}

\section{INTRODUCTION}

IT governance is the structure of relationships, processes and mechanisms used to develop, direct and control IT strategy and resource allocation so as to achieve the goals and objectives of an enterprise. It is a set of formal processes aimed at balancing the risk and return aspects of IT investment so as to consistently add value to the organization. IT governance is ultimately the responsibility of senior executive management. In a broader sense, IT governance encompasses developing the IT strategic plan, assessing the nature and organizational impact of new technologies, formalizing the IT decision-making framework, developing the IT skill base, aligning IT direction and resources, safeguarding the interests of internal-external IT stakeholders as well as taking into account the quality of relationships between stakeholders. (Korac-Kakabadse \& Kakabadse, 2001; ITGI, 2003, Kordel, 2004). Over the long term, IT governance structures help focus an organization on the strategic value of IT and ensures that high-level controls are in place to achieve and sustain benefits (BearingPoint, 2003; ITGI, 2003). More countries are implementing legislative measures to ensure greater accountability from organizations (Ridley and Liu 2004), and more organizations are adopting formal governance processes that specifically address the governance of important business assets including IT. Consequently, IT governance has become an 
integral part of the corporate governance landscape (ITGI, 2003; Van Grembergen, De Haes \& Guldentops, 2004; AS8015, 2005).

The emergence of online technologies has significantly impacted government capacity to provide services. However, while the Internet enables web-based delivery of a range of services it does not in itself improve a government's capacity to perform - especially in an environment of organizational disaggregation of political and administrative control from traditional public-sector governance structures (Baptista, 2005; Dunleavy \& Margetts, 2000). In market-focused organizations, the board and senior management are tasked with the responsibility of implementing governance structures that ensure the efficacy of investment decision-making processes (Weill \& Ross, 2004). However, for many public sector organizations there is a more complex set of accountability relationships in place that spans the electorate, the public service, the government, and the parliament. At the same time, public sector organizations are confronted by ongoing structural changes to how they function and relate to a country's economy and its citizenry. These changes are in turn bringing about a re-evaluation of the appropriateness of governance structures, processes and relational mechanisms in the public sector (Edwards, 2002; Gowland \& Aiken, 2005; Howard \& Seth-Purdie, 2005).

This paper contrasts IT governance issues in the private and public sectors. Our analysis begins with a discussion on the defining characteristics of public and private sector organizations and then expounds more on the IT governance principles by differentiating between IT management and governance. The paper further highlights the implications of public and private sector differences to IT governance approaches. While surveys have shown that many managerial-level IT issues and challenges are similar (Ward and Mitchell, 2004), we argue that there are systemic differences between private and public sector organizations that impact governance.

\section{DEFINING PUBLIC AND PRIVATE SECTOR ORGANIZATIONS}

The distinction between the 'public' and 'private' sectors is not straightforward. Rainey, Backoff \& Levine (1976) attribute this ambiguity in classification to an increasing similarity of role, context and function of organizations in both sectors. This difficulty has become more noticeable with recent public sector reforms, privatization and corporatization activities (Peters and Savoie, 1998). Consequently, different approaches have been used to distinguish between the public and private sector organizations. For example, some investigators have used a denotative approach in which organizational activities are used to differentiate sector membership, while others have adopted a common sense approach which assumes that the reader knows the differences between sectors (Rainey et al., 1976).

Differences are also echoed in the extant literature. For example, many political science models rely on agency theory perspectives to understand political influence on public sector organizations. In contrast, organizational theorists almost exclusively study individual-level behavior in private organizations without reference to the impact of polity on organizational goals (Pandey, 2006). This paper adopts a broad analytic approach that attempts to give a definition of the two sectors. However, we do not claim to provide absolute explanations of the differences and similarities between private and public sector organizations.

As shown in Figure 1, private and public organizations can be defined by the level of government or market influence on ownership and control. In our analysis, the private sector consists of entities 
which are for the large part not government-controlled. However, these entities can be either profitmaking or non-profit-making. As a consequence, profit motive is used to highlight the distinction between organizational forms such as NGOs and charities with mutual organizations and public companies. Private sector non-profit organizations are formed for the purpose of humanitarian service or to undertake advocacy activities on behalf of community interest groups.

In contrast, public sector organizations are a collection of a nation's administrative and economic institutions that provide services and goods for and on behalf of the government. It encompasses the sub-sectors of general government - mostly central/federal, state and local government units as well as government run for-profit corporations. Public sector organizations are generally reliant on government budgetary allocations for their funding (mainly government departments, controlled by Ministers and Government Departmental Directors/Chiefs) - these will be referred to as 'public service' or just 'government'. It also includes 'semi/quasi government' organizations that are selffunded with some revenue flow from the sale of goods and services independent of government budgetary allocations. Examples include hospitals, nursing homes, registration boards, regulatory bodies of different types and statutory authorities. Although they may achieve a surplus, semigovernment organizations do not usually make distributions to owners (Winston, 1997). Somewhat controversially, we have classified universities as just falling into the for-profit/private sector quadrant which largely reflects the historical independence and the increasing market-focus within the Australian higher education sector (Davis, 2005; Meek \& Wood, 1997).

\section{Public Sector}

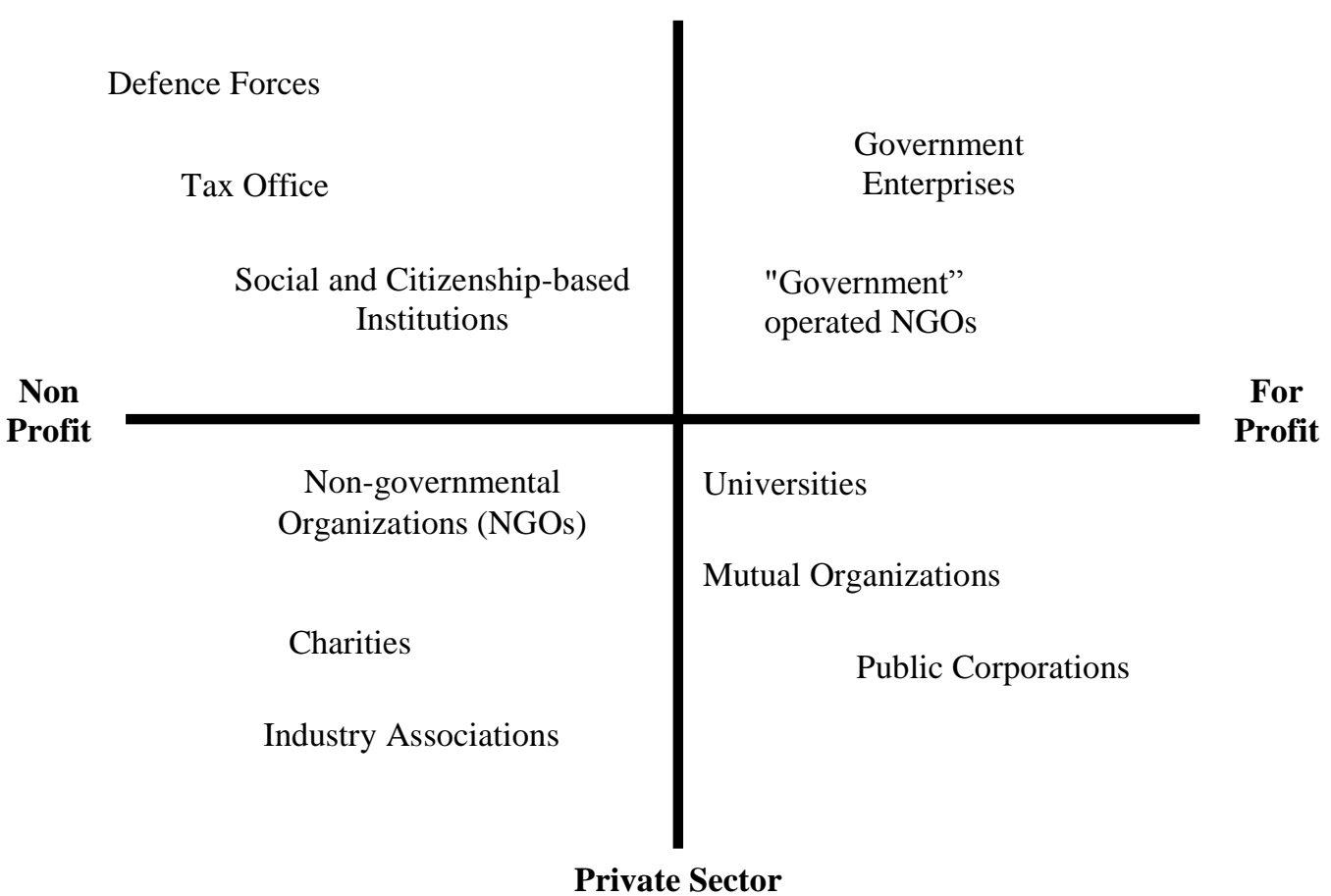

Figure 1: Profit Motive for Private/Public Sectors Organizations 


\section{IT GOVERNANCE VERSUS IT MANAGEMENT}

IT management focuses on the internal effective operation of IT products and services, as well as the administration of existing IT operations. In contrast, IT governance is a higher level activity aimed at ensuring that IT is aligned with the present and future demands and goals of the business and its customers (Van Grembergen et.al., 2004).

The formal conceptualization of IT governance is relatively new. The concept of IT governance emerged in the late nineties as a subject matter for academic research (see the works of Brown, 1997; Sambamurthy \& Zmud, 1999; Peterson, O’Callaghan \& Ribbers, 2000; De Haes \& Van Grembergen, 2005). Before this body of work the use, monitoring and control of IT was largely encapsulated in IT management theories (see for example Watson, 1989). Even today much of the literature does not differentiate IT management from IT governance. The two concepts are often regarded as synonymous, even though they clearly differ (Sohal \& Fitzpatrick, 2002). Figure 2 identifies different aspects of governance and management in an IT context.

Governance
External and internal focus
Whole-of-organization
Future
Strategic
Benefit realization
Wise investment
Delegation

\author{
Management \\ Internal focus \\ Departments \& individuals \\ Present \\ Operations \& projects \\ Cost \& quality \\ Budget accountability \\ Hands-on
}

Figure 2: Governance versus Management

An important differentiator is that management tasks have an internal focus and are done at the unit/departmental level, while IT governance is a corporate level activity with a purposeful external focus (Sohal \& Fitzpatrick, 2002). Management is concerned with what decisions are made, while governance is concerned with who should make decisions and how these decisions will be monitored. A change to an organization's strategy may well require changes to the management but not the governance of an asset (Weill \& Ross, 2004). In IT management, the provision of IT services and products can be assigned to an external provider (as in outsourcing), while IT governance is specific to an organization. Since governance gives direction and control over IT expenditures, it cannot be outsourced and is the direct responsibility of the senior executive (Peterson, 2003).

\section{DIFFERENCES BETWEEN PRIVATE AND PUBLIC SECTORS}

The public sector might be expected to lag behind private sector organizations in the development, implementation and governance of IT (Caudle, Gorr \& Newcomer, 1991). Private sector for-profit organizations can more readily justify risky investments in innovation for competitive advantage (Rocheleau \& Wu, 2002). Private sector non-profit organizations can also be expected to lag their for-profit sector counterparts because of their dependence on voluntary funding (DCITA, 2005). Although private sector organizations do face similar resourcing difficulties, budgetary constraints 
on non-profit and public sector organizations should be more challenging. Consequently, projects that are perceived as being risky are less likely to be considered - even if these projects are, on balance, good investments (Rocheleau \& Wu, 2002). IT managers in these types of organizations have the arduous task of proving IT value over the need to respond to the demand for the organization's services (DCITA, 2005).

The public sector has multiple, mostly intangible or conflicting goals, with programs that have numerous stakeholders with competing interests (Dawes, Pardo, Simon, Cresswell, LaVigne, Andersen \& Bloniarz, 2004). Government priorities and policy direction provide mechanisms to define and scope the achievement of these goals (Gregory \& Borland, 1999). In stark contrast, the private sector is guided by market signals and profit. Whereas in government an agenda 'must' be addressed (such as provide education or supply public health services), the private sector is largely driven by economic feasibility considerations. Consequently, the overarching objectives of private sector organizations are often expressed in terms of financial profitability and efficiency while public sector organizations are frequently judged on their political efficiency and the achievement of their policy mission (Kraemer \& Dedrick, 1996). This obligation to attain societal goals makes the public sector less affected by cyclical movements in the economy (Gregory \& Borland, 1999) but clearly more susceptible to political changes. Non-profits also operate programs that have multiple stakeholders to whom they are accountable and their efficacy is similarly measured by their ability to deliver services or other outcomes to the community (Choudhury \& Ahmed, 2002).

There is also the issue of political influence and periodic structural change within the public sector which can destabilize governance mechanisms. Political cycles can cause periodic disruption in toplevel management. Program priorities in the departments can change significantly with each new administration. These politically induced management changes also result in data discontinuity (Bozeman \& Bretschneider, 1986) thereby weakening governance monitoring. While similar changes can occur in private sector organizations, it is more the exception than the rule.

Environmental factors also accentuate the differences between private and public sectors (Caudle et.al., 1991). For instance, public sector organizations generally have less market exposure and therefore less scope for explicit incentive mechanisms for productivity and effectiveness, but at the same time more legal and formal constraints. As an example, purchasing in the public sector is subjected to many bureaucratic constraints and the process of acquiring new hardware/software can be a drawn out process (Korosec, 2002; Kraemer \& Dedrick, 1996). Generally, public policy processes can make investments and decision-making difficult for public sector IT managers (Dawes et.al., 2004) and reduce implementation success (Peizer, 2003). Public sector managers also face difficulties in developing meaningful incentives for motivating individual performance. Less favorable salary differentials between the public and private sector inevitably contribute to high staff turnover in some skill areas (Gregory \& Borland, 1999; Dawes et.al., 2004). Because of inhouse skill shortages, there is a tendency in Australia for the public sector, non-profit and semigovernment organizations to hire contract staff and/or outsource IT functions. The recently released Gershon Report on the Australian Government's use of ICT highlights the need to move away from contract ICT staff (Gershon, 2008

Sector differences are largely ignored in IT governance and alignment literature (for example, see Chan \& Reich, 2007). From a broader corporate governance perspective, Nicoll (2005) argues that the accountability required of public sector entities is generally greater than for the private sector. Consequently, public sector governance systems that mirror the private sector could arguably 
diminish accountability. This is particularly important in an environment where procedures for assessing governance arrangements are not in place and there is general resistance for a central authority to oversee governance practices (Howard \& Seth-Purdie, 2005). In Australia, the Gershon Report (Gershon, 2008) identified a weakness in pan-government ICT governance which is attributable to high levels of agency autonomy.

As Table 1 shows, there are significant systemic differences between public and private sector organizations due to a multitude of factors such as organizational structure, corporate governance structure, absorptive capacity of IT, organizational IT competence, market competition and stability, government regulations and policies (Brown, 1997; Sambamurthy \& Zmud, 1999; Chin, Brown \& $\mathrm{Hu}, 2004)$. In addition, the primary role of IT as a factor may differ depending on the objectives or strategies pursued by an organization. These may include reduction of costs, provision of support services to individual departments, or to facilitate future business strategies (Weill \& Woodham, 2002; Chin et.al., 2004). It is important to consider these sector differences and to adopt governance structures that encourage desirable behaviors in the application of IT that are appropriate for their organizational and sector setting (Weill \& Ross, 2004).

\begin{tabular}{|c|c|c|c|c|}
\hline \multirow{3}{*}{ Attribute/factor } & \multicolumn{4}{|l|}{ Sector } \\
\hline & \multicolumn{2}{|l|}{ Public } & \multicolumn{2}{|l|}{ Private } \\
\hline & Public service & Profit & Non-profit & Profit \\
\hline Goals & $\begin{array}{l}\text { Multiple and } \\
\text { intangible }\end{array}$ & $\begin{array}{l}\text { Multiple and } \\
\text { tangible }\end{array}$ & Multiple & $\begin{array}{l}\text { Specific and } \\
\text { tangible }\end{array}$ \\
\hline Product & $\begin{array}{l}\text { Provide services } \\
\text { and public goods }\end{array}$ & Sell services & $\begin{array}{l}\text { Provide } \\
\text { services }\end{array}$ & Profit \\
\hline $\begin{array}{l}\text { Achievement } \\
\text { measured by }\end{array}$ & $\begin{array}{l}\text { Political } \\
\text { efficiency \& } \\
\text { achieving policy } \\
\text { mission }\end{array}$ & $\begin{array}{l}\text { Sustainability of } \\
\text { service provision }\end{array}$ & $\begin{array}{l}\text { Achieving } \\
\text { mission }\end{array}$ & $\begin{array}{l}\text { Financial } \\
\text { profitability and } \\
\text { efficiency }\end{array}$ \\
\hline \multirow[t]{3}{*}{ Environmental } & $\begin{array}{l}\text { Less incentives } \\
\text { for productivity }\end{array}$ & $\begin{array}{l}\text { May have more } \\
\text { incentives than } \\
\text { government }\end{array}$ & $\begin{array}{l}\text { No incentives, } \\
\text { uses } \\
\text { volunteers }\end{array}$ & More incentives \\
\hline & $\begin{array}{l}\text { More legal and } \\
\text { formal constraints } \\
\text { - red tape }\end{array}$ & $\begin{array}{l}\text { Less formal } \\
\text { constraints }\end{array}$ & Less red tape & Less red tape \\
\hline & $\begin{array}{l}\text { Political } \\
\text { influences }\end{array}$ & $\begin{array}{l}\text { Some political } \\
\text { and market } \\
\text { influences }\end{array}$ & $\begin{array}{l}\text { Free of } \\
\text { influences }\end{array}$ & $\begin{array}{l}\text { Market } \\
\text { influences }\end{array}$ \\
\hline $\begin{array}{l}\text { Proprietary versus } \\
\text { shared IT }\end{array}$ & $\begin{array}{l}\text { Shares IT } \\
\text { resources, } \\
\text { applications and } \\
\text { technical help }\end{array}$ & $\begin{array}{l}\text { IT is proprietary } \\
\text { to give an edge }\end{array}$ & $\begin{array}{l}\text { Lacks in } \\
\text { sharing of } \\
\text { resources }\end{array}$ & $\begin{array}{l}\text { Treats IT as } \\
\text { proprietary to } \\
\text { stay ahead and } \\
\text { competitive }\end{array}$ \\
\hline
\end{tabular}

Table 1: A summary of differences between sectors

(Sources: Caudle et.al., 1991; Kraemer \& Dedrick, 1996; Dawes et.al., 2004; DCITA, 2005) 


\section{IMPLICATIONS FOR IT GOVERNANCE IN PUBLIC SECTOR ORGANIZATIONS}

Be it in the public or private sector, IT governance can be deployed using a combination of processes, structures and relational mechanisms. Processes could be monitoring, decision-making, service level agreements (SLAs), balanced IT scorecards; structures may include IT councils, committees (such as an IT strategy committee or IT steering committee); while mechanisms could be business partnerships, shared learning, stakeholder participation and collaboration between functional areas, units or workgroups. Figure 2 shows how these elements relate to form an IT governance framework. Each aspect is indispensable to successful IT governance (Weill \& Woodham, 2002; Van Grembergen et.al., 2004).

The structure of the IT function and the position of the decision-making authority in an organization to a large part determines the efficacy of IT governance (Weill \& Ross, 2004). De Haes and Van Grembergen's (2005) study of a Belgian financial services organization (private sector) found that the CIO reported directly to a member of the executive committee. This organization also had an IT strategy committee that operated at the strategic level as well as an IT/business steering committee that decided on new investments while a separate steering group existed for maintenance of the IT projects. All these formed part of an effective governance structure. In another case study by Weill and Ross (2004) on London's Metropolitan Police Service (public service), the executive body is the

Management Board which directly supervises various strategic committees, including the Information Management Steering Group. This committee makes recommendations for IT investments and suggests to the Management Board how to start, stop and fund projects. Project proposals are supervised by designated business sponsors right up to completion. The use of steering committees is a popular way of monitoring and reporting progress, and is commonly used in all sectors (Sohal \& Fitzpatrick, 2002).

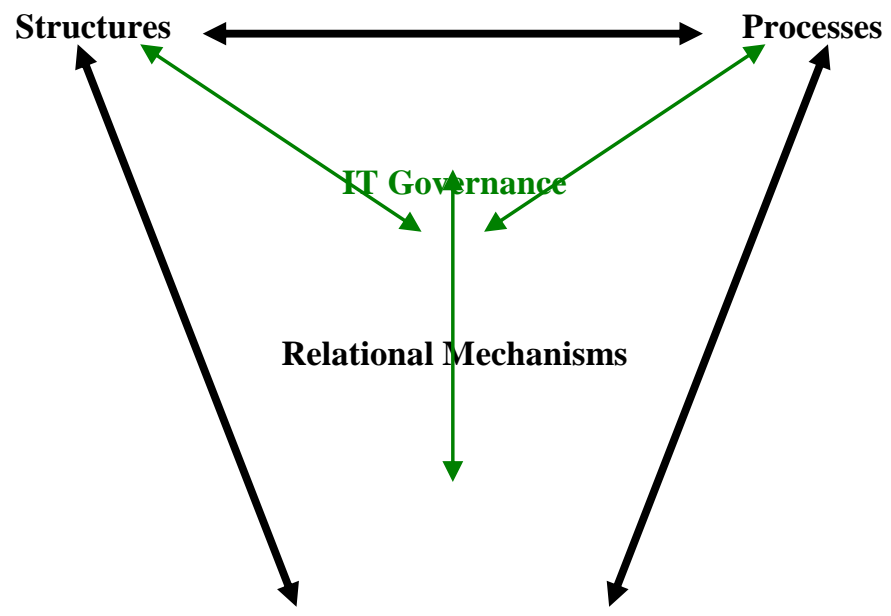

Figure 2: Main elements of an IT governance framework 


\section{IT STRUCTURES}

One of the challenges facing all sectors is limited financial resources (Rocheleau \& Wu, 2002; BearingPoint, 2003). In the public sector, IT spend can sometimes be reduced through a shared services approach or by re-using systems and technologies between other agencies. This sharing of infrastructure is highly feasible as the public sector has greater organizational interdependence than the private sector (Rocheleau \& Wu, 2002). Unfortunately the same cannot be said of non-profits, which DCITA (2005) notes, have similar opportunities but more difficulty in forming strategic partnerships with other organizations to share resources, best practices and infrastructure. In contrast, private sector organizations must maintain their autonomous stance since they operate in competitive markets; an environment that diminishes the value and opportunity to share IT knowledge and applications in the absence of network externalities. The scope of sharing in the private sector is generally reduced to outsourcing high volume and commoditized ICT activities and resources rather than the core technologies and skills-base that can be shared in a whole-ofgovernment approach to ICT governance in the public sector.

IT governance structures in the public sector must balance effectiveness and efficiency in service provision. As Shiller (2004) notes, the private sector should provide goods and services that people can afford, while the public sector should provide only those goods and services for which people are prepared to pay. Publicly provided goods and services cannot be distributed under the same terms as for profit-oriented business. Investment decisions in the public sector should be based on the multiple viewpoints of internal process development and good service provision (Rivenbark, Fitzgerald \& Schelin, 2003). Although not emphatic, a study by Boyne (2002) of the literature on the efficacy of transferring business practices into the public sector found some support for the conjecture that public sector organizations are more bureaucratic, and that public sector managers are less materialistic and have less organizational commitment than their private sector counterparts.

\section{IT PROCESSES}

The private sector is guided by market signals while the public sector is largely guided by societal obligations and concerns. Private sector organizations compete in dynamic and turbulent environment. While public sector organizations are less susceptible to market impacts, their own operating environments are subjected to a different set of forces. Public sector organizations exist in a relatively stable environment occasionally subjected to periodic but deep structural transformations brought about by political change.

Jacobsen (2006) argues that the interaction between political and administrative spheres is determined by formal structures. These structures tend to strengthen over time but elections act as a shock that weakens the effect of the formal structure. Consequently, the political and administrative system then must be rebuilt over time. Decision-making processes for the two sectors systemically differ - in the public sector decision-making can appear to be more methodical and compliance oriented (Gershon, 2008) whereas in the private sector it is sometimes based on more ephemeral considerations (Ribbers, Peterson \& Parker, 2002; Suomi and Tähkäpää, 2004). Attempts at creating artificial market places for ICT are also less successful in the public sector (Gershon, 2008).

There are also unique opportunities for ICT innovation in the public sector. For example, the Australian Tax Office (ATO) has been able to go completely online for individual tax return 
submissions - which it managed by forming strategic alliances with tax agents. Since the undertaking involved external organizations, the ATO had to consider a number of issues like compatibility of external systems with internal systems and internal standards. This highlights the dilemma for IT decision makers and governance in the public sector - the potential of alliances to invest in standard compliant systems is dependent on the willingness of external partners to cooperate (Weill \& Ross 2004). Moreover, the ATO now has another challenge to face: how much should the alliance be reflected within the IT governance decision-making mechanism considering that it is now so closely linked with the government structure?

As the public sector has many layers of authority, this may lead to a lower implementation rate as decisions take longer to be finalized and resourced. In this way compliance requirements, public policy limitations and legacy processes can make investments and decision-making difficult for the $\mathrm{CIO}$ and governance committees. Access to IT funding may also require a strong focus on lowering costs as fund allocations in the public sector are less flexible. Taken together; this points to a complex market-for-service environment that must affect IT decision-making (Suomi \& Tähkäpää, 2004; Weill \& Ross, 2004). In contrast, opportunities may be more easily acted on in the private sector as organizational structure is generally less complex and there are alternative justifications for IT investment beyond cost reduction.

\section{RELATIONAL MECHANISMS}

An organization can have the necessary structures and processes in place, but lack the ability for organizational units and IT to work together. Good collaboration and two-way communication are essential elements in IT governance (Henderson \& Venkatraman, 1999). In De Haes and Van Grembergen's (2005) study, a financial services organization used an IT charter to implement relational mechanisms. This charter explained roles between IT people and business people who were then able to interrelate directly. Moreover, the organization sponsored account management meetings which focused on the relational aspects of projects to bridge the gap between business and IT perspectives. The company also used mechanisms such as training sessions on business activities, job rotations, use of simple, non-technical language as well as a web-based portal for communicating with or educating staff. All these were done to attain active contribution, teamwork and shared understanding between IT and business personnel.

In another study of large Australian organizations, Sohal and Fitzpatrick (2002) showed that many IT functions are either partially or fully outsourced. According to Weill and Ross (2004), senior management can see outsourcing as a quick fix to IT problems without acknowledging that outsourcing success depends on its proper management. Outsourcing appears likely to continue for all sectors leading to smaller IT units and leaving the remaining staff to take on relational and strategic roles (Weill \& Ross 2004). Whether IT is fully or partially outsourced, IT governance structures must accommodate formal and informal relationships between the outsourcing organization and the service provider - a task that is often overlooked (Luftman, Bullen, Liao, Nash \& Neumann 2004).

In terms of leadership (a core plank in all governance frameworks), Woods and Woods (2004) argue that it is difficult to import leadership into the public sector from the private sector. Their study of public sector educational services found that attempts to modernize leadership was itself shaped and altered by the context of the public sector ethos that already existed. 
Having established the importance of structures, processes and relational mechanisms in the governance of IT, it is worth noting that identifying the most appropriate IT governance model is not a straight-forward task. It is difficult to identify all the factors that influence the choice of these elements (De Haes \& Van Grembergen 2005). The best possible mix of structures, processes and relational mechanisms will differ for each organization and depend on multiple contingencies including sector and the operating environment of the organization (Ribbers et.al., 2002).

\section{CONCLUSION}

Bozeman and Bretschneider (1986) first hypothesized that the differences between the public and private sectors require different principles in the management and governance of organizational information systems. A one-size-fits-all approach is not appropriate when studying organizations from across sectors and a failure to address sector differences is a critical mistake when studying IT governance. For example, public sector organizations have opportunities to participate in whole-ofgovernment and cross-agency approaches to IT governance - an opportunity most private organizations do not have. However, the structure of ministerial portfolios and administrative control of agencies may have a silo-like effect that limits the effectiveness of whole-of-government approaches to IT governance.

The alignment of organizational and individual objectives is potentially more difficult in the public sector because of the limited ability to establish market-linked incentives. In Australia, government is highly reliant on contract ICT personnel. Contract rates enable government agencies to compete with the higher salaries paid by private sector organizations. Hiring contract staff also allows agencies to more easily shed positions if the funding environment so demands. This practice can be counterproductive. While contract rates might help keep public sector pay competitive, the pay differential can create tensions between permanent and contract staff. There is also less scope for developing organizational ICT capability.

Despite these contextual differences, there is a paucity of empirical research on public/private sector IT governance. Further studies are clearly needed to establish the governance approaches that work best in a public sector context. Should IT governance structures, processes and relational mechanisms rely on the relatively stable functions of a public service agency, or should we consider the broader and evolving objectives of a whole-of-government approach?

The unique contribution of IT governance to service delivery in government is also an important area to investigate. It would be valuable to understand the extent to which IT is aligned with the objectives of different government agencies. This paper has highlighted some of the systemic differences between the public and private sector IT governance. It is hoped that the issues raised here will provide motivation for empirical research to examine what is currently an under researched area in IT governance.

\section{REFERENCES}

AS8015, (2005). Australian standard for IT Governance. Corporate governance of information and communication technology, Standards Australia Committee IT-030, ICT Governance and Management, SAI Global Business Publishing. 
Baptista, M. (2005). e-Government and State Reform: Policy Dilemmas for Europe. The Electronic Journal of e- Government, 3(4), 167-174.

BearingPoint, (2003), IT governance: Leveraging technology in government, a white paper by BearingPoint Inc. Retrieved on 28th October, 2005 from http://www.bearingpoint.com

Boyne, G.A. (2002). Public and Private Management: What's the Difference? Journal of Management Studies, 39(1), 97-122.

Bozeman, B. \& Bretschneider, S. (1986). Public management information systems: Theory and prescription. Public Administration Review, 46(6), 475-487.

Brown, C.V. (1997). Examining the emergence of hybrid IS governance solutions: Evidence from a single case site. Information Systems Research, 8(1), 69-94.

Brown, C.V. \& Magill, S.L. (1994). Alignment of the IS Functions with the Enterprise: Towards a Model of Antecedents. MIS Quarterly, 18(4), 371-403.

Caudle, S.L., Gorr, W.L. \& Newcomer, K.E. (1991). Key information systems management issues for the public sector. MIS Quarterly, 15(2), 171-189.

Chan, Y.E. \& Reich, B.H. (2007). IT alignment: an annotated bibliography. Journal of Information Technology, 22(4), 316-396.

Chin, P.O., Brown, G.A. \& Hu, Q. (2004). The impact of mergers and acquisitions on IT governance structures: A case study. Journal of Global Information Management, 12(4), 5074.

Choudhury, E. \& Ahmed, S. (2002). The shifting meaning of governance: Public accountability of third sector organizations in an emergent global regime. International Journal of Public Administration, 25(4), 561-588.

Davis, G. (2005). Regulating universities: an assumption and three propositions. Paper for the Melbourne Institute/ The Australian conference on 'Sustaining prosperity', University of Melbourne, 1 April. Accessed 5 October 2008, http://www.unimelb.edu.au/speeches/transcripts/64davis20050401.doc

Dawes, S., Pardo, T.A., Simon, S., Cresswell, A.M., LaVigne, M.F., Andersen, D.F. \& Bloniarz, P.A. (2004). Making smart IT choices: Understanding value and risk in government IT investments, 2nd edn, Centre for Technology in Government, University of Albany, New York.

De Haes, S. \& Van Grembergen, W. (2004). IT governance and its mechanisms. Information Systems Control Journal, 1.

De Haes, S. \& Van Grembergen, W. (2008). Analyzing the Relationship Between IT Governance and Business/IT Alignment Maturity. Proceedings of the 41st Annual Hawaii International Conference on System Sciences (HICSS 2008).

De Haes, S. \& Van Grembergen, W. (2005). IT governance structures, processes and relational mechanisms: Achieving IT/business alignment in a major Belgian financial group. Proceedings of the 38th Hawaii International Conference on System Sciences, IEEE Computer Society.

DCITA, (2005). Department of Communications, Information Technology and Arts, Information and communications technology transforming the non-profit sector, accessed 19 October, 2008 from 
http://www.dcita.gov.au/communications_and_technology/publications_and_reports/2003/03 lovum_report/case16

Dunleavy, P. \& Margetts, H. (2000). The Advent of Digital Government: Public Bureaucracies and the State in eth Internet Age, Paper to the Annual Conference of the American Political Science Association, Omni Shoreham Hotel, Washington, 4 September 2000, http://www.governmentontheweb.net/downloads/papers/APSA_2000.pdf accessed 5 October 2008.

Edwards, M. (2002). Public Sector Governance - Future Issues for Australia. Australian Journal of Public Administration, 61(2), 51-61.

Gershon, P. (2008). Review of the Australian Government's Use of Information and Communication Technology, Australian Government Information Management Office, http://www.finance.gov.au/publications/ict-review/index.html, accessed 30 October 2008.

Gowland, D. \& Aiken, M. (2005). Changes to Financial Management Performance Measures, Accountability Factors and Accounting Information Systems. Australian Journal of Public Administration, 64(3), 88-99.

Gregory, R.G. \& Borland, J. (1999). Recent developments in public sector labor markets. in Handbook of Labor Economics, Ashenfelter, O \& Card, D (ed.), Vol. 3C, Amsterdam: Elsevier.

Henderson, J.C. \& Venkatraman, N. (1999). Strategic alignment: Leveraging information technology for transforming organizations. IBM Systems Journal, 38(2/3), 472-485.

Howard, C. \& Seth-Purdie, R. (2005). Governance Issues for Public Sector Boards. Australian Journal of Public Administration, 64(3), 56-68.

ITGI, (2003). IT Governance Institute, Board briefing on IT governance, 2nd edition, retrieved on 18 August, 2008, from www.itgi.org

Jacobsen, D.I. (2006). The Relationship between Politics and Administration: The Importance of Contingency Factors, Formal Structure, Demography, and Time. Governance, 19(2), 303 323.

Korac-Kakabadse, N. \& Kakabadse, A. (2001). IS/IT governance: Need for an integrated model. Corporate Governance, 1(4), 9-11.

Korosec, R.L. (2002). Non-profit contracting from 1982-1997: A comparison of sector-based factors. International Journal of Public Administration, 25(4), 423-439.

Kordel, L. (2004). IT governance hands-on: using CobiT to implement IT governance. Information Systems Control Journal, 2, 8 pgs.

Kraemer, K.L. \& Dedrick, J. (1996). Computing and public organizations. Center for Research on Information Technology and Organizations, paper 227.

Luftman, J., Bullen, V.C., Liao, D., Nash, E. \& Neumann, C. (2004). Managing the information technology resource: Leadership in the information age. New Jersey: Pearson Prentice Hall.

Meek, V.L. and Wood, F.Q. (1997). The market as a new steering strategy for Australian higher education. Higher Education Policy, 10(3-4), 253-274.

Nicoll, P. (2005). What lies ahead for public sector governance. Keeping Good Companies, 57, 1926. 
Pandey, S.K. (2006). Connecting the Dots in Public Management: Political Environment Organizational Goal Ambiguity, and the Public Manager's Role Ambiguity. Journal of Public Administration Research and Theory, 16(4), 511-532.

Peizer, J., (2003). Cross-sector information and communications technology funding for development: What works, what does not and why. Information Technologies and International Development, 1(2), 81-88.

Peters, G. and Savoie, D. (1998) Taking Stock: Assessing Public Sector Reforms, Canadian Centre for Management Development and McGill-Queen's University Press. Montreal.

Peterson, R.R. (2003). Information strategies and tactics for information technology governance. in Strategies for information technology governance, W. Van Grembergen (ed). Idea Group Publishing.

Peterson, R.R., O'Callaghan, R. \& Ribbers, P.M.A. (2000). 'Information technology governance by design: Investigating hybrid configurations and integration mechanisms. Proceedings of the 21 st International Conference on Information systems, 435-452.

Rainey, H.G., Backoff, R.W. \& Levine, C.H. (1976). Comparing public and private organizations. Public Administration Review, March/April, 233-244.

Ribbers, P.M.A., Peterson, R.R. \& Parker, M.M. (2002). Designing information technology governance processes: Diagnosing contemporary practises and theories. IEEE Proceedings of the 35th Hawaii International Conference on System Sciences (HICCS).

Ridley, G. \& Liu, Q. (2004). IT Governance Disclosure of Web100 Companies. Proceedings of the 11th European Conference on IT Evaluation, 11-12 Nov, 12 pgs.

Rivenbark, W.C., Fitzgerald, K.M. \& Schelin, S.H. (2003) Analyzing information technology investments in State Government. Social Science Computer Review, 21(4), 497-505.

Rocheleau, B. \& Wu, L. (2002). Public versus private information systems: Do they differ in important ways? A review and empirical test. American Review of Public Administration, 32(4), 379-397.

Sambamurthy, V. \& Zmud, R.W. (1999). Arrangements for information technology governance: A theory of multiple contingencies. MIS Quarterly, 23(2), 261-290.

Shiller, E. (2004). Don't run government like a business. retrieved on 10th August, 2008 from http://www.edshiller.com/note.asp?id=37

Sohal, A.S. \& Fitzpatrick, P. (2002). IT governance and management in large Australian organizations. International Journal of Production Economics, 75, 97-112.

Suomi, R. \& Tähkäpää, J. (2004). Governance structures for IT in the Health Care industry. in Strategies for information technology governance, W. Van Grembergen (ed), p. 357-381. Idea Group Publishing. Hershey (PA).

Trites, G. (2004). Director Responsibility for IT Governance. International Journal of Accounting Information Systems, 5, 89-99.

Van Grembergen, W., De Haes, S. \& Guldentops, E. (2004). Structures, processes and relational mechanisms for information technology governance: Theories and practices. in Strategies for information technology governance, W. Van Grembergen (ed), Idea Group Publishing. Hershey (PA). pp. 1-36. 
Ward, M.A. and Mitchell, S. (2004). A comparison of the strategic priorities of public and private sector information resource management executives. Government Information Quarterly, 21(3), 284-304.

Watson, R.T. (1989) Key issues in information systems management: An Australian perspective1988. The Australian Computer Journal, 21(2), 118-129.

Weill, P. (2004). Don't Just Lead, Govern: How Top-Performing Firms Govern. MIS Quarterly Executive, 3(1), 1-17.

Weill, P. \& Ross, J.W. (2004). How top performers manage IT decision rights for superior results. Harvard Business School Press. Boston.

Weill, P. \& Woodham, R. (2002). Don't just lead, govern: Implementing effective IT governance. CISR Working Paper, April, 2002, http://dspace.mit.edu/handle/1721.1/1846.

Winston, G.C. (1997) Why can’t a college be more like a firm? Change, 29(5), 32-38.

Woods, P. and Woods, G. (2004). Modernizing leadership through private participation: a marriage of inconvenience with public ethos? Journal of Education Policy, 19(6), 643-672. 